Check for updates

The BMJ

kabbasi@bmi.com Follow Kamran on Twitter@KamranAbbasi Cite this as: BMJ2020;371:m4586 http://dx.doi.org/10.1136/bmj.m4586 Published: 26 November 2020

\title{
The curious case of the Danish mask study
}

\section{Kamran Abbasi executive editor}

DANMASK-19, the first trial of mask use during covid-19, was “negative.” Masks didn’t work. We knew this before the trial was published because we were told so on social media. The authors were reported by the media to be struggling to find a major journal for their trial. ${ }^{1}$ Journals weren't proving brave enough to publish the study, said the authors, and they didn't make a preprint available.

When the mythical trial was finally published last week in the Annals of Internal Medicine we didn't need to read it. We already knew its damning verdict on mask wearing. Social media told us as much. Eminent professors of evidence based medicine, Carl Heneghan and Tom Jefferson, confirmed this in an article for the Spectator. ${ }^{2}$

Except that if you read the published paper you find almost the exact opposite. ${ }^{3-5}$ The trial is inconclusive rather than negative, and it points to a likely benefit of mask wearing to the wearer-it did not examine the wider potential benefit of reduced spread of infection to others-and this even in a population where mask wearing isn't mandatory and prevalence of infection is low. This finding is in keeping with summaries of evidence from Cochrane.

A disagreement among experts, especially about interpretation of a study, is a common occurrence. It is the usual business of science. Only, Facebook didn't see it that way. The social media platform that allows statements about injecting bleach to prevent covid-19, as well as calls to behead the leading US expert on pandemics, ${ }^{67}$ decreed that Heneghan and Jefferson should be censured for misinformation after they reposted their Spectator article on the site.

It is possible to disagree with Heneghan and Jefferson about the robustness and interpretation of the DANMASK-19 trial-which I do-and still believe it is wrong that their opinion of it was marked as "false information." ${ }^{8}$ It seems 2020 is Orwell's 1984, where the boundaries of public discourse are governed by multibillion dollar corporations (in place of a totalitarian regime) and secret algorithms coded by unidentified employees. Where is Facebook's accountability for the lies and damaging misinformation ${ }^{910}$ that it has peddled on controversial topics such as mental health and suicides, ${ }^{11}$ minorities, ${ }^{12}$ and vaccines ${ }^{13}{ }^{14}$ ?

The problem is less that Facebook and other social media decide what is published on their platforms, ${ }^{15}$ just as The BMJ's editors decide what is published on bmj.com. Sacha Baron Cohen and Carole Cadwalladr, among others, have argued that this is exactly what these tech giants should do. ${ }^{16}{ }^{17}$ It is more that Facebook in particular purports to allow freedom of speech on its platform but acts selectively, seemingly without logic, consistency, or transparency. That is how control of facts and opinions furthers hidden agendas and manipulates the public.

You might expect a national body like Public Health England to offer the best advice on mask wearing, but PHE is no more after seven years of controversy. ${ }^{18}$ Its proximity to government and industry, together with funding cuts to local authorities, essentially set it up to fail and now to become the government's fall guy for a flawed pandemic response. PHE is being replaced by a national institute for health protection, which may well be closer still to government and industry. When accountable national organisations move in the direction of political and commercial interests, public trust is eroded, and the power of unaccountable and self-serving social media platforms only grows.

Why won't anyone publish the Danish mask study? 17 Nov 2020 https://worldhealth.net/news/why-wont-anyone-publish-danish-maskstudy.

2 Heneghan C, Jefferson T. Landmark Danish study finds no significant effect for facemask wearers. Spectator 2020. https://www.spectator.co.uk/article/do-masks-stop-the-spread-of-covid-19-

3 Alex Nowbar's research reviews-28 November 2020. https://blogs.bmi.com/bmi/category/weekly-research-reviews.

4 Brophy JM. Covid-19: controversial trial may actually show that masks protect the wearer. BMJ Opinion. 24 Nov 2020.

https://blogs.bmj.com/bmj/2020/11/24/covid-19-controversial-trial-mayactually-show-that-masks-protect-the-wearer.

5 Bundgaard H, Bundgaard JS, Raaschou-Pedersen DET, etal. Effectiveness of adding a mask recommendation to other public health measures to prevent SARS-CoV-2 infection in Danish mask wearers: a randomized controlled trial. Ann Intern Med 2020. doi: 10.7326/M20-6817. pmid: 33205991

6 https://www.nytimes.com/2020/04/30/technology/trump-coronavirussocial-media.html.

7 Smith A. Facebook: Steve Bannon's call for Anthony Fauci to be beheaded do not break its rules, Zuckerberg says. Independent. 13 Nov 2020. https://www.independent.co.uk/life-style/gadgets-and-tech/steve-bannonanthony-fauci-behead-zuckerberg-facebook-b1722335.html.

8 Heneghan C. Twitter. 20 Nov 2020. https://twitter.com/carlheneghan/status/1329861848573861888.

9 Morgan M. Matt Morgan: The two pandemics-covid and lies. BMJ 2020;371:m4516doi: 10.1136/bmj.m4516.

10 Salisbury H. Helen Salisbury: Careless communication costs lives. BMJ 2020;371:m4383doi: 10.1136/bmj.m4383.

11 John A, Pirkis J, Gunnell D, Appleby L, Morrissey J. Trends in suicide during the covid-19 pandemic. BMJ2020;371:m4352.

doi: 10.1136/bmj.m4352 pmid: 33184048

12 Khunti K, Routen A, Pareek M, Treweek S, Platt L. The language of ethnicity. BMJ 2020;371:m4493. doi: 10.1136/bmj.m4493 pmid: 33229395

13 Will AJ. covid-19 vaccines be cost effective-and does it matter?BMJ 2020;371:m4491.

14 Mahase E. Covid-19: What do we know about the late stage vaccine candidates?BMJ 2020;371:m4576doi: 10.1136/bmj.m4576.

15 Oliver D. David Oliver: Should we bring the curtain down on NHS social media performances?BMJ2020;371:m4497.

16 Baron Cohen S. Read Sacha Baron Cohen's scathing attack on Facebook in full: "greatest propaganda machine in history." Guardian. 22 Nov 2019. https://www.theguardian.com/technology/2019/nov/22/sacha-baron-cohenfacebook-propaganda.

17 Cadwalladr C. If you're not terrified about Facebook, you haven't been paying attention. Guardian. 26 Jul 2020. https://www.theguardian.com/commentisfree/2020/jul/26/with-facebook-we-are-already-through-the-lookingglass 
18 Vize R. Controversial from creation to disbanding, via e-cigarettes and alcohol: an obituary of Public Health England. BMJ 2020;371:m4476. doi: 10.1136/bmj.m4476 pmid: 33218977

This article is made freely available for use in accordance with BMJ's website terms and conditions for the duration of the covid-19 pandemic or until otherwise determined by BMJ. You may use, download and print the article for any lawful, non-commercial purpose (including text and data mining) provided that all copyright notices and trade marks are retained. 